\title{
Ricardian Equivalence Hypothesis in the Sub-Sahara African Countries
}

\author{
Grace Ofori-Abebrese \\ Department of Economics, Kwame Nkrumah University of Science and Technology, Kumasi, Ghana \\ Robert Becker Pickson \\ College of Economics and Management, Sichuan Agricultural University, Chengdu, China
}

\begin{abstract}
The validity of the Ricardian equivalence proposition remains disputed in spite of the numerous empirical studies. This study utilized panel ARDL estimation approach to investigate the evidence of Ricardian Equivalence Hypothesis in five Sub-Sahara African countries, namely Botswana, Ghana, Gambia, Nigeria, and Kenya over the period of 1981 2014. The results show that GDP per capita and interest rate have significant positive impacts on private consumption, whereas government debt, government spending, and government interest payment on the outstanding debt have negative impacts on private consumption. From the perspective of this study, the Ricardian equivalence hypothesis, which states that private consumption remains unchanged regardless of government's spending, does not hold in Sub-Sahara African countries.
\end{abstract}

JEL Classifications: E4, E21, E31, H5, H6, H63

Keywords: Ricardian equivalence, Interest rate, Government debt, Government spending, Government debt interest payments, Inflation

\footnotetext{
* Corresponding Author: Robert Becker Pickson; College of Economics and Management, Sichuan Agricultural University, 211 Huimin Road, Wenjiang District, Chengdu, China; E-mail: myselfpickson@yahoo.com

Co-Authors: Grace Ofori-Abebrese; Department of Economics, Kwame Nkrumah University of Science and Technology, Kumasi, Ghana.
} 


\section{Introduction}

Keynes (1936) explained that changes in government spending and tax policies can influence the level of national output and that an increase in budget deficit leads to an increase in real domestic product and in private consumption. A government may sometimes spend more than its revenues in an effort to stir up a slumping economy. For instance, commissioning roads and bridges increase demand for construction workers, services, and supplies. This translates into higher incomes and purchases of other goods and services that tend to spur the spending power in the economy. The same argument applies to a policy of cutting taxes or tax rebates. Lower taxes mean higher disposable incomes and higher profits which might encourage high spending.

David Ricardo developed a theory which is now called the Ricardian Equivalence Theorem. The theory basically says that if taxes are decreased or spending is increased, then the government incurs a debt at least in the future. The government must pay this debt off in the future with either increased taxes or decreased spending. He believed that people are as smart as being able to perceive it, save the money they receive from the government today and invest it. So they can pay back the government in the future. The Ricardian equivalence contrary to Keynes's view has argued that fiscal policy measures would, therefore, have no effect on aggregate demand and therefore national output because the increase in spending caused by the government would be matched by the same decreases in spending from the private sector.

Spending of private agents would not change because they recognize that a reduction in taxes today are expected to increase future tax liabilities and that is why they will save the entire tax cut, leaving private consumption unchanged. Private agents are rational and know that when the government reduces tax in order to stimulate consumption and increase national output, cuts in taxes imply a later pressure to raise taxes since the government has to fill the resource gap in the budget which is the result of the initial tax cut. So, rational economic agents will put the additional income from the tax cut into savings and consumption will not rise.

Modern governments typically finance their spending in two ways: taxing or borrowing. If the government taxes, then current taxpayers fund government activities. If the government funds its activities by borrowing, and if the government does not default on the bonds it issues when it borrows, 
the interest on government debt must be paid by future taxpayers. So, while deficits avoid the need for the government to impose taxes when it spends, the borrowing really just shifts taxation to future taxpayers. The key question raised by Ricardian equivalence is whether this shift in the timing of taxation affects the ability of government spending to stimulate or constrain aggregate demand. The proposition is called the equivalence hypothesis because it implies that, given a path of government spending, lump-sum tax and bond finance lead to the same economic choices by agents and therefore are equivalent for all issues of interest.

Barro (1974) provided some theoretical foundation for Ricardian proposition by assuming that families act as infinitely lived dynasties because of intergenerational altruism, capital markets are perfect, i.e., all can borrow and lend at a single rate, and the path of government expenditures is fixed. He argued that given these conditions if governments finance deficits by issuing bonds, interest earned on bonds would be large enough to offset the higher taxes that will be needed to pay off those bonds. He concluded that in the case where the marginal net-wealth effect of government bonds is close to zero, fiscal effects involving changes in the relative amounts of tax and debt finance for a given amount of public expenditure would have no effect on private consumption, aggregate demand, interest rates, and capital formation.

Barro (1979) buttressed his views by defining the Ricardian Equivalence Theorem as shifts between debt and tax finance for a given amount of public expenditure that would have no first-order effect on the real interest rate, the volume of private investment, etc.

Empirical studies such as Kormendi (1983), Seater and Mariano (1985), and Kormendi and Meguire (1995) have concluded that budget deficits do not influence consumption in the countries they have studied and therefore found support for the validity of the Ricardian equivalence.

Contrary, Cardia (1997), Elmendorf and Liebman (2000), Gale and Potter (2002) among others have concluded that the hypothesis does not hold in the countries they have studied. This outcome of Ricardian equivalence model is based on some assumptions that some economists consider to be strong. Studies such as Gale and Potter (2002) have raised concerns about whether or not taxpayers actually behave in the ways that the Ricardian equivalence model requires. The theory requires taxpayers to appreciate how changes in government fiscal measures will change their spending habits and for that 
matter affect them throughout their lives. The theory also implies that the value current taxpayers place on the consumption of future taxpayers, perhaps their children, is the same as theirs. A thorough study of the hypothesis posts that the Ricardian equivalence overlooks some important features of Keynesian's theory. Keynes has established that each level of spending creates new incomes when resources are unemployed so those new incomes will spur further spending to increase aggregate demand and national output. In addition, when the government issues bonds, it creates a new asset for the holders of government bonds but the Ricardian equivalence considers it as just a liability for future taxpayers.

Many developing countries have resorted to high tax rates to address these challenges but the concern is how these have been able to help reduce budget deficits and to spur on growth. The purpose of this study is to test empirically the validity of the Ricardian Equivalence Hypothesis in some Sub-Sahara African countries, namely Botswana, Ghana, The Gambia, Nigeria, and Kenya.

The rest of the paper is structured as follows. Section 2 provides a review of the literature in connection with the Ricardian Equivalence Hypothesis. Section 3 presents the data sources, model specification, and analytical techniques. Section 4 shows the analysis of empirical results. Eventually, Section 5 gives a summary and concluding remarks.

\section{Literature}

Keynesian macroeconomics postulates that if government fiscal policy is to raise demand, the output will be higher, as long as the economy has underutilized resources. If Keynes assumption holds then the key question raised by the Ricardian equivalence is whether higher government spending or lower taxes would stimulate demand or if taxpayers would take into account the implications of today's spending for taxes in the future.

The theoretical case of Ricardian equivalence is mostly demonstrated in a model of an infinitely lived representative agent under these assumptions such as fully rational, optimizing behaviour, perfect capital markets and nondistortionary taxation. Under these circumstances, it can be shown that for a given level of government expenditures, the tax-debt composition does 
not have any real effects. Agent simply recognizes that debt always implies taxation in the future with the present value of future taxes being precisely equal to the amount of debt issued. It is argued that if the government borrows money to fund a tax cut, rational consumers realise that in the future taxes will have to be raised to finance the borrowing. Therefore, they save the extra income so that they can pay future tax raised. Wheeler (1999) argued that Ricardian equivalence entails that an increase in budget deficits should have a negative impact on interest rates, output, and private consumption.

The theoretical foundation for Ricardian equivalence is not clearly so straightforward when individuals have a finite horizon. Suppose the economy is of the Paul Samuelson (1958)-Peter Diamond (1965) type. Individuals live exactly two periods in a succession of overlapping generations and derive utility only from their own consumption. The government raises funds through an income tax and deficits. Ricardian equivalence will not hold because current lower taxes to current generations which are paid for by the issues of government bonds will be redeemed with taxes levied on future generations. Here, the mode of financing government spending will not change so the issue of bonds will have a wealth effect and therefore alter macroeconomic activity. The same result will hold in models in which individuals live more than two periods as long as some of the future taxes implied by debt are borne by future generations. It would appear that finite horizons eliminate the possibility of Ricardian equivalence, for there always are some people whose current tax reduction will not be matched by future tax payments.

In summary, fiscal policy is very likely to affect demand, even if taxpayers anticipate future tax implications. Changes in today's government spending almost certainly matter for today's demand. When demand is higher, income will be higher if that demand can mobilize unemployed resources (Keynes 1936). If income is higher than it would have been without more government spending, it makes sense for people to spend more, even if they fully anticipate the implications of any resulting deficits for future taxes and future bond payments financed by those taxes. Tax cuts that increase disposable income can raise demand either because people expect such changes to matter for the spending of others or because households do not, or perhaps cannot, comprehend the implications of today's tax cuts for future tax liabilities.

However, Barro (1974) proved that Ricardian equivalence holds in the 
finite horizon model. He conditioned that if people consider the future of their children as a continuation of their lives then when the government cuts tax, parents will save the increase in their disposable income and bequeath to their children enough wealth to allow them to pay for future taxes that the government may impose as a result of the deficits. This has come to be known as altruism. Becker (1995) showed that as budget deficits change, private consumption also changes depending on how risk averse the individuals are. The author found support for the Ricardian equivalence for some specific utility functions.

This indicates that the Ricardian equivalence holds when life is certain and there is altruism because according to Blanchard (1985) if individuals die before all taxes implied by current debts are collected then the model will not hold. He stressed further that people would recognize that some future taxes would be borne, at least in probability, by people whose utilities do not matter to them and so would prefer debt to current taxes. Studies such as Katz (1979) have clarified that life is uncertain therefore an accurate model of intertemporal planning has an infinite horizon, thus a positive probability of dying at each age, and a finite expected lifetime. Bernheim and Abel (1988) have argued that altruism is not the only reason why parents bequeath wealth to their children, but there are other possible motives such as mutual insurance by family members, and simple accident arising from uncertain lifetimes among others. They concluded that the existing body of theory and evidence do not justify claims that government borrowing has little or no effect on the economy but there is the likelihood that deficits have large effects on current consumption and interest rate. Kotlikoff and Spivak (1981) also believe that families unconsciously act as incomplete annuities markets. According to them, families provide insurance to their members against risk of low consumption that might arise as a result of an unexpectedly long life. Thus, transfer among family members occurs in a manner of insurance services. Abel (1985) also added that bequeath of wealth occurs in most instances because life is uncertain and people die earlier than anticipated and therefore pass on their wealth to their children with no intention of altruism.

The study of Weil (1989) established that although it is not clear that only altruistic bequests can generate Ricardian equivalence but it is essential for it to hold in the infinite horizon model. He argued that if parents were not altruistic in such a model, they would alter their economic decisions in 
response to a debt-for-tax swap and would not bequeath any extra wealth to their children to pay increased future taxes.

Martins (1980, 1995) attempted to assess the Ricardian equivalence proposition by integrating interest rate and public debt (government's debts on securities) in a theoretical framework. Araujo-Martins (1999) developed a model; Capital Accumulation Model, based on this development but did not set interest rate to be a function of government debt. The study further used the $\mathrm{AK}$ production function in order to assess the effects of government debt on output growth rates by the use of the Ricardian equivalence proposition. They came out that generations do not behave as if they were infinitely lived, thus Ricardian equivalence results are not expected to hold.

Moreover, Rock et al. (1989) empirically examined the validity of the Ricardian equivalence proposition in Trinidad and Tobago and Barbados. They reported that the case of Trinidad and Tobago did not support the Ricardian equivalence but that of Barbados supported the Ricardian equivalence. Drakos (2001) used the Ricardian equivalence proposition to explore the long-run relationship between government borrowing and private savings in Greece. The study revealed that as budget deficit increased, households perceived government bonds as net wealth, hence they increased their consumption, without considering the uncertainty of the future tax level. Using first cointegration analysis, Vamvoukas (2001) tested the Ricardian equivalence and the Keynesian proposition for Greece and found support for the Keynesian proposition. Ghatak and Ghatak (1996) attempted to examine the validity of the Ricardian equivalence in India and found no support for this proposition. Khalid (1996) investigated the validity of the Ricardian equivalence for 17 developing countries. The study found support for the Ricardian equivalence for 12 out of the 17 developing countries.

Walker (2002) used data span 1990 2000 to investigate the validity of the Ricardian proposition in Japan. The study found that cuts in taxes had zero or negligible effect on output and therefore supports the Ricardian proposition. The implications for Japan are that a tax cut would provide a low stimulus or none on output. On the spending side, an increase in government spending and budget deficits cause a positive impact on output and private consumption, but at a diminishing rate. Issler and Lima (2000) examined the validity of the Ricardian equivalence by assessing the effects of public debt on consumption behaviour in Brazil. The study found the behaviour of a 
rational consumer in Brazil to be consistent with Ricardian equivalence.

In addition, Domenech et al. (2000) tested the Ricardian equivalence for a panel of OECD countries and their results invalidated it since private savings compensated only a small portion of the budget deficit. Giorgioni and Holden (2003) studied the Ricardian equivalence for ten developing economies (Ethiopia, El Salvador, Honduras, Pakistan, India, Sri Lanka, Morocco, Burundi, Nigeria, and Zimbabwe). The results showed a negative relationship between budget deficits and consumption, although it was found not to be significant. The study indicated that the existence of the Ricardian Equivalence Hypothesis in these countries.

Meanwhile, Sunge et al. (2015) analysed the Ricardian Equivalence Hypothesis in Zimbabwe and found strong evidence against the Ricardian Equivalence Hypothesis. His results exhibited the evidence of Keynesian debt non-neutrality in Zimbabwe. Also, Keho (2016) noted that, in the longrun, budget deficit and GDP per capita have significant positive effects on private consumption, whilst inflation is detrimental to private consumption in the West African Economic and Monetary Union (WAEMU) member countries. This implies that limiting the size of the budget deficits might have a deleterious effect on the development of WAEMU member countries.

From the critical assessment of the literature above, the reports on the available empirical evidence are ambiguous for both developed and developing economies. This makes this study significant as it enriches related literature and provides valuable information to policymakers of the examined economies in their fiscal policy measures.

\section{Econometric Methodology}

\section{A. Model specification}

To examine the validity of the Ricardian equivalence proposition, the study drawn on the empirical studies such as Feldstein (1982), Kormendi (1983), Aschauer (1985), Seater and Mariano (1985), Blinder and Deaton (1985), Evans (1988), and Haug (1990) who all converged in estimating the following structural consumption function, although Barro (1989) expressed doubts about the quality of this model. 


$$
P C_{t}=f\left(Y_{t}, W H_{t}, G D_{t}, G S_{t}, T T_{t}, S S_{t}, T R_{t}\right)
$$

where $P C_{t}$ is a measure of private consumption, $Y_{t}$ is the current income, $W H_{t}$ is household wealth, $G D_{t}$ is government debt, $G S_{t}$ is a measure of government purchases, $T T_{t}$ are total tax proceeds, $S S_{t}$ is a measure of social security claims, and $T R_{t}$ are government transfers to private households.

However, due to certain difficulties in having reliable data for household wealth, social security claims, total tax proceeds, and government net transfers to the private households, these variables were excluded from the model. As such, the study rather incorporated interest rate (IR), and government interest payments on the outstanding debt (GIPD), and inflation (INFL) into the empirical model. To this end, the Equation (1) can be expressed as:

$$
P C_{t}=\beta_{0}+\beta_{1} Y_{t}+\beta_{2} G D_{t}+\beta_{3} G S_{t}+\beta_{4} I R_{t}+\beta_{5} G I P D_{t}+\beta_{6} I N F L_{t}+\varepsilon_{t}
$$

By transforming the Equation (2) into natural log model, the Equation (3) is written as follows:

$$
\begin{gathered}
\ln P C_{t}=\beta_{0}+\beta_{1} \ln Y_{t}+\beta_{2} \ln G D_{t}+\beta_{3} \ln G S_{t}++\beta_{4} \ln I R_{t}+\beta_{5} \ln G I P D_{t} \\
+\beta_{6} \ln I N F L_{t}+\varepsilon_{t}
\end{gathered}
$$

According to the Ricardian Equivalence Hypothesis, the consuming pattern of the individuals is not affected by the choice that the government makes in order to finance its expenditures. This implies that the government debt exerts no wealth effects on private consumption $\left(\beta_{2}=0\right)$. Also, government expenditures negatively influence private consumption since they lead to higher future taxes $\left(\beta_{3}<0\right)$. Besides, the higher the interest rates, individuals will substitute their current consumption with future consumption $\left(\beta_{4}<0\right)$, and since government interest payments on the outstanding debt are expected, its coefficient should be zero $\left(\beta_{5}=0\right)$. Inflation lowers the real value of assets and incomes, as such, it is expected to ultimately have a negative impact on private consumption $\left(\beta_{6}<0\right)$. Hence, the Ricardian Equivalence Hypothesis 
imposes that $\beta_{2}=\beta_{5}=0$, while $\beta_{3}<0$ and $\beta_{4}<0$.

\section{B. Data}

The study utilized annual time series data for five Sub-Sahara African (SSA) countries, namely The Gambia, Ghana, Nigeria, Botswana, and Kenya. All the data covered the period 1981 2014. Data on private consumption, GDP per capita, government debt, government spending, interest rate proxied by deposit interest rate, government interest payments on the outstanding debt, and inflation were sourced from the World Development Indicators database by the World Bank.

\section{Analytical techniques}

\section{Panel unit root test}

Prior to the data analysis, Im-Pesaran-Shin (IPS) test was utilized to observe the presence of unit root which means that data is non-stationary. ImPesaran-Shin test provides individual results of each cross section. IPS test is the extended form of Levin-Lin test where lagged dependent variables are used as regressors while allowing heterogeneity on the coefficient of lagged dependent variables. The IPS test commences by specifying the Augmented Dickey-Fuller regression as presented by:

$$
\Delta y_{i t}=\tau_{i}+\rho_{i} y_{i, t-1}+\sum_{j=1}^{p_{i}} \delta_{i j} \Delta y_{i, t-j}+\varepsilon_{i t}
$$

for $i=1, \ldots, N$ and $t=1, \ldots, T$.

The null hypothesis is that unit root exists:

$$
H_{0}: \rho_{i}=0
$$

The alternative hypothesis states that there is the absence of unit root, i.e., the slope coefficients are less than zero. 


$$
H_{1}: \rho_{i}<0
$$

Where $\rho_{i}$ is the order of the Augmented Dickey-Fuller regression, and $\varepsilon_{i t}$ indicated the errors which are independently distributed. IPS assumes to have a balanced panel so the time, $\mathrm{T}$ assumes to fixed for all cross-sections to compute the individual test statistic. The test is based on average individual unit root tests;

$$
\bar{t}=\frac{1}{N} \sum_{i=1}^{N} t \rho_{i}
$$

If this statistic is properly standardized, it is asymptotically $N(0,1)$ distributed. Im-Pesaran-Shin test requires $N /{ }_{T} \rightarrow 0$ for $N \rightarrow \infty$.

\section{Pooled mean group estimation}

After examining the stationarity of the variables concerned, the study used latest econometric techniques including panel unit root test and pooled mean group estimation approach, which is also known as panel autoregressive distributed lag (ARDL) model for the balanced dataset. A pooled mean group (PMG) estimation technique provides homogeneity of the coefficients in dynamic panel data analysis across cross sections and allows heterogeneous dynamics in the short-run (Pesaran et al. 1999). This implies that in this approach, the slope coefficients may perhaps differ in short-run same as in Mean Group (MG) estimator, but homogeneous in the long-run. This study applied pooled mean group estimation technique or panel ARDL approach to examine the short-run and long-run effects of independent variables on the dependent variable. The generalized form of the panel ARDL can be expressed as:

$$
P C_{i, t}=\sum_{j=1}^{m} \gamma_{i, j} P C_{i, t-j}+\sum_{j=0}^{n} \omega_{i j} D_{i, t-j}+\mu_{i}+\varepsilon_{i t}
$$


where the regressand $\left(P C_{i t}\right)$ is private consumption and its lagged values are used as regressors while $D_{i, t}$ variables include GDP per capita, government debt, government spending, interest rate, government interest payment on the outstanding debt, and inflation, $\omega_{i j}$ are the 4 by 1 coefficient vectors, $\gamma_{i j}$ are the scalars, and $\mu_{i}$ indicates the country-specific effect.

If the variables are cointegrated, in that case, the disturbance term is an $\mathrm{I}(0)$ process. The key feature of the cointegrated variables deduces the shortrun dynamics of the variables which are influenced by the deviance from the long-run relationship. Accordingly, it is prevalent to re-parameterized the above equation into the unrestricted error correction equation as:

$$
\Delta P C_{i t}=\varphi_{i} p c_{i, t}-\theta_{i} D_{i, t-j}+\sum_{j=1}^{m-1} \gamma_{i j} \Delta p c_{i, t-j}+\sum_{j=0}^{n-1} \omega_{i j} \Delta D_{i, t-j}+\mu_{i}+\varepsilon_{i t}
$$

where $\theta_{i}$ indicates the long-run coefficients, and $\varphi_{i}$ presents the speed adjustment. If $\varphi_{i}$ is zero, it implies that there exists no evidence of longrun relationship among the variables. It is anticipated that $\varphi_{i}$ is significantly negative under the prior presupposition that the variables converge to the long-run equilibrium in the presence of any disturbance in the system. The optimum lag length of regressand and regressors are determined using STATA 14.2 software.

\section{Empirical Results}

\section{A. Descriptive statistics}

The descriptive statistics of the variables used in this study are presented in Table 1. 


\section{Table 1. Descriptive Statistics}

\begin{tabular}{|l|c|c|c|c|c|}
\hline \multicolumn{1}{|c|}{ Variable } & Obs. & Mean & Std.Dev. & Min & Max \\
\hline Ln(private consumption) & 170 & 4.178608 & 0.300532 & 3.255542 & 4.558606 \\
\hline Ln(GDP per capita) & 170 & 6.580643 & 0.937576 & 5.030932 & 8.941835 \\
\hline Ln(government debt) & 170 & 3.759143 & 0.860918 & 1.617866 & 5.266161 \\
\hline Ln(government purchases) & 170 & 2.621566 & 0.455315 & 1.575519 & 3.998484 \\
\hline Ln(interest rate) & 170 & 2.543302 & 0.441789 & 0.929947 & 3.590163 \\
\hline $\begin{array}{l}\text { Ln(government interest payment } \\
\text { on the outstanding debt) }\end{array}$ & 170 & 18.01875 & 1.677957 & 15.36817 & 22.32138 \\
\hline Ln(inflation) & 170 & 2.422515 & 0.810156 & -0.168455 & 4.811164 \\
\hline
\end{tabular}

There are 170 observations representing the yearly panel data from 1981 to 2014. The standard deviation of the variables indicates variation or deviation of the series from their mean values. All the series indicated little deviation from the mean values. This is because the extent of deviation from the mean value is not substantial for private consumption, GDP per capita, government debt, government spending, interest rate, and inflation. However, the standard deviations of government interest payments on the outstanding debt were found to be substantial. Private consumption averaged around 4.18 percent over the 1981 2014 period, whilst GDP per capita, government debt, and government spending averaged around 6.58 percent, 3.76 percent, and 2.62 percent over the same period respectively. The interest rate recorded an average of 2.54 percent over the 1981 2014 period, whilst the government interest payment of the outstanding debt and inflation averaged 18.02 percent and 2.42 percent over the same period respectively. Moreover, the private consumption indicated a maximum rate of 4.56 percent and a minimum of 3.26 percent. The minimum level of government debt over the study period was 1.62 percent whilst the maximum 5.27 percent. In addition, the government spending showed a minimum of 1.58 percent over the period with a maximum of 4.0 percent. The interest rate recorded a minimum of 0.93 percent and a maximum of 3.59 percent. 


\section{B. Panel unit root test results}

The study employed Im-Pesaran-Shin test to examine the presence of unit root. The results of the panel unit root test are therefore presented in Table 2.

Table 2. Results of panel unit root test

\begin{tabular}{|c|c|c|c|}
\hline \multirow{3}{*}{ Variables } & \multirow{2}{*}{\multicolumn{2}{|c|}{\begin{tabular}{|c|} 
Im-Pesaran-Shin \\
Level \\
\end{tabular}}} & \multirow{3}{*}{$\begin{array}{l}\text { Order of } \\
\text { Integration }\end{array}$} \\
\hline & & & \\
\hline & $\begin{array}{l}\text { Individual } \\
\text { Intercept }\end{array}$ & $\begin{array}{c}\text { Individual } \\
\text { Intercept and Trend }\end{array}$ & \\
\hline Ln(private consumption) & $-4.59087 * * *$ & $-4.57888 * * *$ & $\mathrm{I}(0)$ \\
\hline $\operatorname{Ln}(G D P$ per capita $)$ & 1.15393 & 0.11181 & \\
\hline Ln(government debt) & 0.38310 & 0.33395 & \\
\hline Ln(government purchases) & -1.01500 & 0.11728 & \\
\hline Ln(interest rate) & $-1.40819^{*}$ & -0.83720 & \\
\hline $\begin{array}{l}\text { Ln(government interest } \\
\text { payment on the } \\
\text { outstanding debt) }\end{array}$ & $-1.36101^{*}$ & $-1.90947 * *$ & $\mathrm{I}(0)$ \\
\hline Ln(inflation) & $-2.74903 * * *$ & $-2.8103 * * *$ & $\mathrm{I}(0)$ \\
\hline \multirow{3}{*}{ Variables } & \multicolumn{2}{|c|}{ Im-Pesaran-Shin } & \multirow{3}{*}{$\begin{array}{c}\text { Order of } \\
\text { Integration }\end{array}$} \\
\hline & \multicolumn{2}{|c|}{ First Difference } & \\
\hline & $\begin{array}{l}\text { Individual } \\
\text { Intercept }\end{array}$ & $\begin{array}{c}\text { Individual } \\
\text { Intercept and Trend }\end{array}$ & \\
\hline$\Delta \operatorname{Ln}($ GDP per capita $)$ & $-7.73724 * * *$ & $-7.41391 * * *$ & $\mathrm{I}(1)$ \\
\hline$\Delta$ Ln(government debt) & $-6.82293 * * *$ & $-6.95281 * * *$ & $\mathrm{I}(1)$ \\
\hline $\begin{array}{l}\Delta L n \\
\text { (government purchases) }\end{array}$ & $-8.11924 * * *$ & $-7.30473 * * *$ & $\mathrm{I}(1)$ \\
\hline$\Delta L n$ (interest rate) & $-7.11854 * * *$ & $-6.61610 * * *$ & $\mathrm{I}(1)$ \\
\hline
\end{tabular}

(Note) The signs ***,**, and * indicate significance 1 percent, 5 percent, and 10 percent level respectively. 
From the obtained results, private consumption, government interest payment on the outstanding debt and inflation were found to be stationary at their levels and hence integrated of order zero [I(0)]. The rest of the variables such as government debt, government spending, interest rate, and government interest payment on the outstanding debt became stationary at their first difference and integrated of order one [I(1)]. Since the unit root results indicated the integration of orders; zero and one [i.e. I(0) and I(1)], it is therefore appropriate to proceed to the estimation of the panel ARDL model.

\section{Mean group and pooled group estimates}

Table 3 presents the results of the Pooled Mean Group (PMG) and the Mean Group (MG) estimations coupled with the Hausman test statistic.

It is imperative to note that the Pooled Mean Group estimator restricts the long-term coefficients to be the same across countries but allows short-run and adjustment coefficients to differ across countries. Mean Group estimator allows the slope coefficients in both short-term and long-term to vary across countries and turns parameters as averages of the $\mathrm{N}$ individual group regressions. Hausman test was conducted so as to examine the null hypothesis that all countries have the same long-term coefficients. It was obvious from the results obtained in Table 3 that the null hypothesis of homogeneous long-run elasticity is accepted at 5 percent given that the $p$-value is bigger than 0.05. Hence, Pooled Mean Group Estimation is a valid estimator. Unexceptionally, Mean Group regression detects long-run coefficients which are all insignificant and less precise. Accordingly, the study focused the empirical analysis on the results attained from the Pooled Mean Group estimator.

The results of the long-run parameters indicated that GDP per capita has a significant positive effect on private consumption in Sub-Sahara African countries. This implies that an increase in GDP per capita causes an upsurge in the average level of private consumption. In relation to Keho (2016), economic growth has been effective in increasing the average level of private consumption, even though it has not resulted in poverty reduction in the West African Economic and Monetary Union member countries.

Government debt revealed a negative but significant impact on household consumption. This suggests that a decline in government debt increases 
household consumption in Sub-Sahara African countries. This result opposes the Ricardian Equivalence Hypothesis, but it is consistent with Keynesian crowding-out effect. However, government debt has no significant impact on private consumption in the short-run indicating that fiscal policy does not adversely influence private demand in the short-run.

Also, all other factors being equal, government spending is negatively related to private consumption in the long-run. With the coefficient of -0.192 , private consumption will significantly decrease by 0.19 percent as a result of a 1 percent increase in government spending in Sub-Sahara African countries. Thus, fiscal policies that promote excessive government spending might have adverse impacts on private consumption (Keho 2016). Again, it was apparent from the results that government spending maintained its expected signs in the short run just like in the long run. Government spending has a negative coefficient of 0.004 in the short-run, though not statistically significant at any acceptable level. The sign of the variable is in line with theory since government spending is expected to negatively affect the level of private consumption in the long run and not in the short run.

The long-run results further indicated that interest rate has a highly significant positive effect on private consumption. Thus, a percentage change in the interest rate translates into 0.16 percent increase in the average level of private consumption. Government interest payment on the outstanding debt was statistically significant at 5 percent and has a prospective negative marginal impact of 0.10 percent on private consumption for a 1 percent increase in the level of government interest payment on the outstanding debt in SSA countries.

Eventually, in consonant with economic theory and a priori expectation, inflation was found to relate negatively to the average level of private consumption. It was significant at 5 percent with the possibility of reducing private consumption by 0.03 percent for each 1 percent increase in the rate of inflation in SSA countries during the period under study. 
Table 3. Mean group and pooled group estimates

\begin{tabular}{|c|c|c|c|c|c|}
\hline \multicolumn{5}{|c|}{ Dependent Variable: Ln(private consumption) } & \multirow{3}{*}{$\begin{array}{c}\begin{array}{c}\text { Hausman } \\
\text { test }\end{array} \\
p \text {-Value }\end{array}$} \\
\hline \multirow[t]{2}{*}{ Variables } & \multicolumn{2}{|c|}{$\begin{array}{c}\text { Pooled Mean Group } \\
\text { Estimation }\end{array}$} & \multicolumn{2}{|c|}{$\begin{array}{l}\text { Mean Group } \\
\text { Estimation }\end{array}$} & \\
\hline & Coefficient & $z$-Ratio & Coefficient & $z$-Ratio & \\
\hline Ln(GDP per capita $)$ & $0.120 * *$ & 11.95 & 0.101 & 1.40 & \multirow{6}{*}{0.9034} \\
\hline Ln(government debt) & $-0.044 * *$ & -2.23 & 0.061 & 0.83 & \\
\hline Ln(government purchases) & $-0.192 * *$ & -4.82 & -0.106 & -1.15 & \\
\hline Ln(interest rate) & $0.164 * *$ & 8.59 & 0.074 & 1.36 & \\
\hline $\begin{array}{l}\text { Ln(government } \\
\text { interest payment on the } \\
\text { outstanding debt) }\end{array}$ & $-0.104 * *$ & -11.38 & -0.148 & -2.21 & \\
\hline Ln(inflation) & $-0.032 * *$ & -5.20 & 0.023 & 0.46 & \\
\hline \multicolumn{5}{|c|}{ Dependent Variable: $\Delta L n$ (private consumption) } & \\
\hline \multirow[t]{2}{*}{ Variables } & \multicolumn{2}{|c|}{$\begin{array}{c}\text { Pooled Mean Group } \\
\text { Estimation }\end{array}$} & \multicolumn{2}{|c|}{$\begin{array}{c}\text { Mean Group } \\
\text { Estimation }\end{array}$} & \\
\hline & Coefficient & $z$-Ratio & Coefficient & $z$-Ratio & \\
\hline$\Delta L n(G D P$ per capita $)$ & -0.122 & -1.65 & -0.149 & -1.58 & \\
\hline$\Delta L n($ government debt) & -0.017 & -0.63 & -0.086 & -1.98 & \\
\hline$\Delta L n$ (government purchases) & -0.004 & -0.03 & -0.036 & -0.40 & \\
\hline$\Delta L n$ (interest rate) & -0.038 & -1.68 & -0.047 & -0.84 & \\
\hline $\begin{array}{l}\Delta \operatorname{Ln}(\text { government } \\
\text { interest payment on the } \\
\text { outstanding debt) }\end{array}$ & $0.314 * *$ & 2.50 & $0.058 * *$ & 2.97 & \\
\hline$\Delta \operatorname{Ln}($ inflation $)$ & 0.017 & 1.56 & 0.002 & 0.13 & \\
\hline Ect & $-0.474 * *$ & -2.60 & $-0.817 * *$ & -6.62 & \\
\hline Constant & $2.669 * *$ & 2.53 & $4.712 * *$ & 7.45 & \\
\hline
\end{tabular}

(Note) The sign $* *$ indicates significance 5 percent level. 


\section{Conclusion}

The validity of the Ricardian equivalence proposition remains controversial in spite of the numerous empirical studies. This study utilized panel ARDL estimation approach to investigate the evidence of Ricardian Equivalence Hypothesis in five Sub-Sahara African countries, namely Botswana, Ghana, Gambia, Nigeria, and Kenya over the period 1981 2014. The results showed that GDP per capita and interest rate have significant positive impacts on private consumption, whereas government debt, government spending, government interest payment on the outstanding debt have negative impacts on private consumption. From the perspective of this study, the Ricardian Equivalence Hypothesis, which states that private consumption remains unchanged regardless of government's spending, does not hold in Sub-Sahara African countries.

Received 6 June 2018, Revised 27 August 2018, Accepted 30 August 2018

\section{References}

Abel, A. B. "Precautionary saving and accidental bequests." The American Economic Review 75(4) (1985): 777-791.

Abel, A. B., \& Bernheim, B. D. "Fiscal policy with impure intergenerational altruism." National Bureau of Economic Research, Working Paper No. 2613 (1988).

Araujo, J. T., and Martins, M.A.C. "Economic growth with finite lifetimes." Economics Letters 62 (1999): 377-381.

Aschauer, D. A. "Fiscal policy and aggregate demand." The American Economic Review 75(1) (1985): 117-127.

Barro, R. "The Ricardian approach to budget deficits." Journal of Economic 
Perspectives 3(2) (1989): 37-54. http://dx.doi.org/10.1257/jep.3.2.37.

Barro, R. J. “Are Government Bonds Net Wealth?” Journal of Political Economy 82(6) (1974):1095-1117.

Barro, R. J. "On the determination of the public debt." Journal of political Economy 87(5, Part 1) (1979): 940-971.

Becker, T. Budget Deficits, Tax Risk and Consumption. Working Paper Series in Economics and Finance, Stockholm School of Economics, Working Paper No 74. (1995).

Blanchard, O. J. Debt, deficits, and finite horizons. Journal of Political Economy 93(2) (1985): 223-247.

Blinder, A. S., Deaton, A., Hall, R. E., \& Hubbard, R. G. "The time series consumption function revisited." Brookings Papers on Economic Activity 1985(2) (1985): 465-521.

Cardia, E. "Replicating Ricardian Equivalence Tests with Simulated Series." American Economic Review 87 (1997): 65-87.

Diamond, P. A. " National debt in a neoclassical growth model." The American Economic Review 55(5) (1965): 1126-1150.

Domenech, R., Taguas, D. and Varela, J. "The effects of budget deficits on national saving in the OECD." Economics Letters 69 (2000): 377-83.

Drakos, K. "Testing the Ricardian Equivalence Theorem: Time Series Evidence from Greece.” Journal of Economic Development 26 (2001): 149-160.

Elmendof, D. W., and Liebman, J. B. "Social Security Reform and National Saving in an Era of Budget Surpluses." Brookings Papers on Economic Activity (2000):1-71. 
Evans, P. “Are consumers Ricardian? Evidence for the United States.” Journal of Political Economy 96(5) (1988): 983-1004.

Feldstein, M. Government deficits and aggregate demand. Journal of Monetary Economics 9(1) (1982): 1-20.

Gale, W. G., and Potter, S. R. "An Economic Evaluation of the Economic Growth and Tax Relief and Reconciliation Act of 2001." National Tax Journal 54(2002): 133-186.

Ghatak, A. and Ghatak, S. "Budgetary Deficits and Ricardian Equivalence: The Case of India, 1950-1986.". Journal of Public Economics 60, 2 (1996): 267-282.

Giorgioni, G., \& Holden, K. "Does the Ricardian equivalence proposition hold in less developed countries?" International Review of Applied Economics 17(2) (2003): 209-221.

Haug, A. A. "Ricardian Equivalence, rational expectations and the permanent income hypothesis." Journal of Money, Credit and Banking 22(3) (1990): 305326.

Im, K.S., Pesaran, M.H. and Shin, Y. "Testing for Unit Roots in heterogeneous Panels." Journal of Economics 115(2003): 53-74.

Issler, J. V., \& Lima, L. R. "Public Debt Sustainability and Endogenous Seigniorage in Brazil: Time Series Evidence from 1947-1992." Journal of development Economics 62, 1(2000): 131-147.

Keho, Y. "Impact of Budget Deficit on Private Consumption in WAEMU Countries: Evidence from Pooled Mean Group Estimation." International Journal of Economics and Finance 8(3) (2016): 189-195.

Keynes, J. M. "The general theory of interest, employment and money." 
London: McMillan. (1936).

Khalid, A. M. "Ricardian equivalence: empirical evidence from developing economies." Journal of Development Economics 51(2) (1996): 413-432.

Kormendi, R. C. "Government debt, government spending, and private sector behavior." The American Economic Review 73(5) (1983): 994-1010.

Kormendi, R. C., \& Meguire, P. "Government debt, government spending, and private sector behavior: reply." The American Economic Review 76(5) (1986): 1180-1187.

Kotlikoff, L. J., \& Spivak, A. "The family as an incomplete annuities market." Journal of Political Economy 89(2) (1981): 372-391.

Martins, M.A.C. "A nominal theory of the nominal rate of interest and the price level." Journal of Political Economy 88(1980): 174-185.

Martins, M.A.C. "Bonds, interests and capital accumulation." Revista Brasileira de Economia 49(1995): 557-582.

Pesaran, M.H., Shin, Y., \& Smith, R.P.(1999). "Pooled mean group estimation of dynamic heterogeneous panels." Journal of the American Statistical Association 94(446) (1999): 621-634. http://dx.doi.org/10.2307/2670182.

Rock, L. L., Craigwell, R. C., \& Sealy, R. C. (1989). "Public deficits and private consumption: empirical evidence from small open economies." Applied economics 21(5) (1989): 697-710.

Samuelson, P.A. "An exact consumption-loan model of interest with or without the social contrivance of money." The Journal of Political Economy 66 (1958): 467-482.

Seater, J. J., \& Mariano, R. S. "New tests of the life cycle and tax discounting 
hypotheses." Journal of Monetary Economics 15(2) (1985): 195-215.

Sunge, R., Mufandaedza, S., \& Matsvai, S. "Testing the Ricardian Equivalence Hypothesis in Zimbabwe: An ARDL Bound Testing Approach.” Journal of Economics and Sustainable Development 6(11) (2015): 117-128.

Vamvoukas, G. A. "The Relationship Between Budget Deficits and Current Account." Archives of Economic History 12(2001): 57-76.

Walker, W.C. "Ricardian equivalence and fiscal policy effectiveness in Japan." Asian Economic Journal 16(3)(2002): 285-302.

Weil, P. "Overlapping families of infinitely-lived agents." Journal of public economics 38(2) (1989):183-198.

Wheeler, M. "The Macroeconomic impacts of government debt: An empirical analysis of the 1980s and the 1990s." Atlantic Economic Journal 27(3) (1999):273-285. http://dx.doi.org/10.1007/BF02299578. 